\title{
New Substituted Mono-and Bis(imidazolyl)pyridines and their Application in Nitroaldolisation Reaction* $^{*}$
}

\author{
R. KEDER, P. DRABINA, J. HANUSEK, and M. SEDLÁK ${ }^{* *}$ \\ Department of Organic Chemistry, Faculty of Chemical Technology, University of Pardubice, CZ-532 \\ 10 Pardubice, Czech Republic e-mail: milos.sedlak@upce.cz
}

New chiral nitrogen ligands based on the substituted mono-and bis(imidazolyl)pyridines have been prepared and characterised. Their complexes with cupric acetate were used as catalysts in the nitroaldolisation reaction. In the case of optically pure complexes of mono(imidazolyl)pyridine, the isolated products were 2-nitro-1-(2-nitrophenyl)ethanols or 2-nitro-1-(4-nitrophenyl)ethanols in overall yields of $49-93 \%$ and with the maximum enantiomeric excess of $15.6 \%$. The complexes of bis(imidazolyl)pyridine also catalyse the nitroaldol reaction, the yields being $64-90 \%$, but with zero enantioselective excess.

Keywords: imidazolylpyridines, catalysis, copper complex, aldolisation reaction

In recent years, the development of new chiral ligands and their complexes with transition metals has been dynamically increasing $[1,2]$. These complexes are predominantly exploited as homogeneous catalysts within a broad spectrum of asymmetrical syntheses [3]. The ligands prepared in this study on the basis of mono- and bis(imidazolyl)pyridines are formally similar to the ligands with oxazolines "Pymox" [4] and "Pybox" [5], which belong among the best-known and widely applied nitrogen ligands. One of the most advantageous reactions for creating new $\mathrm{C}-\mathrm{C}$ bonds at mild conditions is nitroaldolisation reaction [6-21]. It is a reaction of carbonyl compound and nitroalkane having $\alpha$ hydrogen atom, which is usually catalysed by metal complexes in the presence of bases (tertiary amines, sodium acetate) [6-12]. Another possibility consists in the catalysis by weak Lewis acids, which are components in complexes with mildly basic ligands (carboxylates) that can act as bases and deprotonate nitroalkane [13-21]. The product of nitroaldolisation reaction is $\beta$-hydroxynitroalkane, which can further be reduced to 1,2-amino alcohol, can undergo the Neff reaction to give the respective carbonyl compound, or can be dehydrated to nitroalkene $[19,22]$. In the previous paper, the synthesis and characterisation of (R,S)-, (R,R)-, (S,S)-2,6-bis(4-isopropyl-4-methyl-4,5-dihydro-1Himidazol-5-on-2-yl)pyridines and their complexes with ferric chloride was described [23].

The aim of the present paper is the synthesis and characterisation of new chiral optically pure 2-(4isopropyl-1,4-dimethyl-4,5-dihydro-1H-imidazol-5-on-2-yl)pyridine (I ) and 2,6-bis(4-isopropyl-1,4dimethyl-4,5-dihydro-1H-imidazol-5-on-2-yl)pyridine (II ). These ligands were prepared by Nmethylation of the optically pure 2-(4-isopropyl-4-methyl-4,5-dihydro-1Himidazol-5-on-2-yl)pyridine or 2,6-bis(4-isopropyl-4-methyl-4,5-dihydro-1H-imidazol-5-on-2-yl)pyridine (Scheme 1).

\footnotetext{
${ }^{*}$ Presented at the 57th Congress of Chemical Societies, Tatranské Matliare, 4-8 September 2005.

${ }^{* *}$ The author to whom the correspondence should be addressed.
} 
<smiles>CC(C)C1(C)N=C(c2cccc(C3=NC(C)(C(C)C)C(c4cccc(C5=NC(C)(C(C)C)C(=O)N5C)n4)N3)n2)NC1=O</smiles>

Scheme 1

Starting ligands [8] (3.6 mmol each) were mixed in argon atmosphere with potassium t-butoxide (5.4 mmol or $11.3 \mathrm{mmol}$, respectively) and the reaction mixtures were stirred at room temperature for $1 \mathrm{~h}$. After that, t-butyl alcohol was distilled off under reduced pressure and the evaporation residues were dissolved in $10 \mathrm{~mL}$ of dry DMF. The reaction mixtures were cooled under argon atmosphere and treated with methyl iodide ( $6 \mathrm{mmol}$ or $13 \mathrm{mmol}$, respectively). The suspensions formed were stirred at room temperature for $3 \mathrm{~h}$, whereupon DMF was distilled off and the evaporation residues were mixed with water. The suspensions obtained were extracted using two times $30 \mathrm{~mL}$ of ether and filtered through a plug of silica. Removal of the ether by distillation gave oily products I and II, respectively (Tables 1 and 2).

Table 1. Characterisation Data of the Newly Prepared Ligands

\begin{tabular}{|c|c|c|c|c|c|c|}
\hline \multirow{2}{*}{ Ligand } & \multirow{2}{*}{ Formula } & \multicolumn{3}{|c|}{$\begin{array}{c}w_{\mathrm{i}}(\text { found }) / \% \\
w_{\mathrm{i}}(\text { calc. }) / \%\end{array}$} & \multirow{2}{*}{$\begin{array}{c}{[\alpha]_{25}^{\mathrm{D}}} \\
\text { Solvent, } \rho /\left(\mathrm{g} \mathrm{dm}^{-3}\right)\end{array}$} & \multirow{2}{*}{$\frac{\text { Yield }}{\%}$} \\
\hline & & $\mathrm{C}$ & $\mathrm{H}$ & $\mathrm{N}$ & & \\
\hline$I a$ & $\mathrm{C}_{13} \mathrm{H}_{17} \mathrm{~N}_{3} \mathrm{O}$ & $\begin{array}{l}67.24 \\
67.51\end{array}$ & $\begin{array}{l}7.62 \\
7.41\end{array}$ & $\begin{array}{l}18.38 \\
18.17\end{array}$ & $\begin{array}{c}\quad+28.6 \\
\mathrm{CH}_{2} \mathrm{Cl}_{2}, 6.1\end{array}$ & 65 \\
\hline$I b$ & $\mathrm{C}_{13} \mathrm{H}_{17} \mathrm{~N}_{3} \mathrm{O}$ & $\begin{array}{l}67.35 \\
67.51\end{array}$ & $\begin{array}{l}7.54 \\
7.41\end{array}$ & $\begin{array}{l}18.29 \\
18.17\end{array}$ & $\begin{array}{c}-27.8 \\
\mathrm{CH}_{2} \mathrm{Cl}_{2}, 5.1\end{array}$ & 64 \\
\hline$I I a$ & $\mathrm{C}_{21} \mathrm{H}_{29} \mathrm{~N}_{5} \mathrm{O}_{2}$ & $\begin{array}{l}65.81 \\
65.77\end{array}$ & $\begin{array}{l}7.70 \\
7.62\end{array}$ & $\begin{array}{l}18.45 \\
18.26\end{array}$ & $\begin{array}{c}+32.0 \\
\mathrm{CH}_{3} \mathrm{OH}, 3.0\end{array}$ & 84 \\
\hline$I I b$ & $\mathrm{C}_{21} \mathrm{H}_{29} \mathrm{~N}_{5} \mathrm{O}_{2}$ & $\begin{array}{l}65.86 \\
65.77\end{array}$ & $\begin{array}{l}7.72 \\
7.62\end{array}$ & $\begin{array}{l}18.35 \\
18.26\end{array}$ & $\begin{array}{c}-33.4 \\
\mathrm{CH}_{3} \mathrm{OH}, 4.0\end{array}$ & 83 \\
\hline
\end{tabular}

Table 2. Spectral Data of the Newly Prepared Ligands

\begin{tabular}{|c|c|}
\hline Ligand & Spectral data \\
\hline$I a, I b$ & $\begin{array}{l}{ }^{1} \mathrm{H} \text { NMR }\left(\mathrm{DMSO}-d_{6}\right), \delta: 8.70\left(\mathrm{~d}, 1 \mathrm{H}, \mathrm{PyH}_{6}\right), 8.04\left(\mathrm{~d}, 1 \mathrm{H}, \mathrm{PyH}_{3}\right), 7.99\left(\mathrm{~m}, 1 \mathrm{H}, \mathrm{PyH}_{5}\right), 7.60\left(\mathrm{~m}, 1 \mathrm{H}, \mathrm{PyH}_{4}\right), 3.27 \\
\left(\mathrm{~s}, 3 \mathrm{H}, \mathrm{NCH}_{3}\right), 1.94(\mathrm{~m}, 1 \mathrm{H}, i-\mathrm{PrCH}), 1.24\left(\mathrm{~s}, 3 \mathrm{H}, \mathrm{CH}_{3}\right), 0.95\left(\mathrm{~d}, 3 \mathrm{H}, i-\mathrm{PrCH}_{3}\right), 0.73\left(\mathrm{~d}, 3 \mathrm{H}, i-\mathrm{PrCH}_{3}\right) \\
{ }^{13} \mathrm{C} \text { NMR }\left(\mathrm{DMSO}-d_{6}\right), \delta: 186.0,159.2,149.1,149.0,137.7,126.0,124.0,73.0,34.4,29.0,21.3,16.9,16.7\end{array}$ \\
\hline$I I a, I I b$ & $\begin{array}{l}{ }^{1} \mathrm{H} \text { NMR }\left(\mathrm{DMSO}-d_{6}\right), \delta: 8.26(\mathrm{~m}, 3 \mathrm{H}, \mathrm{Py}), 3.29\left(\mathrm{~s}, 6 \mathrm{H}, \mathrm{NCH}_{3}\right), 2.01(\mathrm{~m}, 2 \mathrm{H}, i-\mathrm{PrCH}), 1.32\left(\mathrm{~s}, 6 \mathrm{H}, \mathrm{CH}_{3}\right), 1.20(\mathrm{~d}, \\
6 \mathrm{H}, i \text {-PrCH}), 0.81\left(\mathrm{~d}, 6 \mathrm{H}, i-\mathrm{PrCH}_{3}\right) \\
{ }^{13} \mathrm{C} \text { NMR }\left(\mathrm{DMSO}-d_{6}\right), \delta: 185.9,159.0,148.3,138.2,126.1,73.2,34.4,28.8,20.8,16.8,16.7\end{array}$ \\
\hline
\end{tabular}




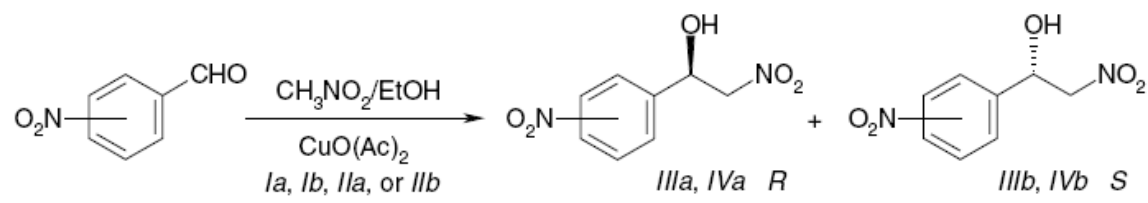

Scheme 2

Table 3. Reaction Conditions, Yield, and Optical Purity of Products

\begin{tabular}{cccccc}
\hline Ligand & Product & Time $/ \mathrm{h}$ & Temperature $/{ }^{\circ} \mathrm{C}$ & Yield $/ \%$ & Optical purity $/ \% *$ \\
\hline$I(R)$ & $I I I(R)$ & 168 & 0 & 89 & 15.6 \\
$I(R)$ & $I I I(R)$ & 10 & 25 & 93 & 13.7 \\
$I I(S, S)$ & $I I I(S)$ & 70 & 25 & 64 & 0.5 \\
$I(S)$ & $I V(S)$ & 336 & 0 & 75 & 14.4 \\
$I(S)$ & $I V(S)$ & 19 & 25 & 90 & 10.5 \\
$I I(S, S)$ & $I V(S)$ & 40 & 25 & 2.0 \\
\hline
\end{tabular}

*Determined by means of HPLC (Chiracel OD-H column; $85: 15$ hexane, propan-2-ol, $0.8 \mathrm{~mL} \mathrm{~min}^{-1}, 220 \mathrm{~nm}$ ).

These new optically pure substituted mono- and bis(imidazolyl)pyridines can be applied as N,Nbidentate ligands (I) and N,N,N-tridentate ligands (II ) to form complexes with metals. In order to evaluate the catalytic properties of these complexes the enantioselective nitroaldol ("Henry") reaction was chosen. As the starting substrates 2-nitrobenzaldehyde or 4-nitrobenzaldehyde were chosen. Their reaction with nitromethane (Scheme 2) was catalysed by the complexes formed in situ from the chiral ligand I or II and cupric acetate, where the acetate anion acts as a base. The products of chosen nitroaldol reaction were 2-nitro-1-(2-nitrophenyl)ethanols (III ) and 2-nitro-1-(4-nitrophenyl)ethanols (IV ), respectively. Table 3 summarises the yield of isolated products ranging between $49 \%$ and $93 \%$.

According to the data presented in Table 3, the complexes derived from N,N,N-tridentate ligand II catalyse the nitroaldol reaction, but almost without asymmetrical induction. The negligible enantioselective yield can be caused by the low stability of the complex in the solution, where the noncoordinated acetate ion operates as another catalytic species. The reaction catalysed exclusively by the complexes as reactive species derived from ligands II is either considerably slow, or does not proceed at all. Lower catalytic activity of the complexes comprising N,N,Ntridentate ligand II can be attributed to the steric effects, e.g. compared to complexes derived from 2,6-bis(4-isopropyl-2-oxazolin-2yl)pyridines used for the same reaction but not containing the two methyl groups situated at the two stereogenic centres [6-21].

Nitroaldol reaction carried out in the presence of complexes derived from N,N-bidentate ligands I, which have only a single stereogenic centre, showed an asymmetric induction with the maximum optical yields of $15.6 \%$ and $14.4 \%$ for 2-nitrobenzaldehyde and 4-nitrobenzaldehyde, respectively. It is generally known that the optical yields are significantly affected by temperature, and this is also obvious from the data of the table. In the case of complexes derived from the compound I, further decrease of temperature would probably somewhat increase the optical yield, however, the reaction time would be inappropriately longer.

In conclusion, it can be stated that the complexes of monosubstituted pyridine I with one stereogenic centre are not sufficiently sterically rigid for attaining a high enantioselectivity in nitroaldol reaction. On the other hand, the complexes derived from the disubstituted pyridine II are probably too sterically demanding to catalyse this reaction at all.

Acknowledgements. The authors acknowledge the financial support from the MSM 00021627501 and the Science Foundation of the Czech Republic, Grant No. 203/04/0646. 


\section{REFERENCES}

1. Jacobsen, E. N., Pfaltz, A., and Yamamoto, H. (Eds.), Comprehensive Asymmetric Catalysis. Springer, Berlin,

1. 1999.

2. Seyden-Penne, J., in Chiral Auxiliaries and Ligands in Asymmetric Synthesis. Wiley-VCH, New York, 1995.

3. Ojima, I. (Ed.), Catalytic Asymmetric Synthesis. 2nd Edition, Wiley-VCH, New York, 2000.

4. Davies, D. L., Fawcett, J., Garratt, S. A., and Russell, D. R., J. Chem. Soc., Dalton Trans. 2004, 3629.

5. Desimoni, G., Faita, G., and Quadrelli, P., Chem. Rev. 103, 3119 (2003).

6. Henry, L. C. R., Acad. Sci., Ser. C 1895, 1265.

7. Henry, L. C. R., Bull. Soc. Chim. Fr. 13, 999 (1895).

8. Ono, N., The Nitro Group in Organic Synthesis. Wiley-VCH, New York, 2001.

9. Patai, S. (Ed.), The Chemistry of Amino, Nitroso, Nitro and Related Groups. Wiley, Chichester, 1996.

10.Feuer, H. and Nielsen, A. T. (Eds.), Nitro Compounds: Recent Advances in Synthesis and Chemistry. VCH, Weinheim, 1990.

11.Rosini, G. and Ballini, R., Synthesis 1895, 833.

12.Seebach, D., Colvin, E. W., Leher, F., and Weller, T., Chimia 33, 1 (1979).

13.Palomo, C., Oiarbide, M., and Mielgo, A., Angew. Chem., Int. Ed. Engl. 43, 5442 (2004).

14.Sasai, H., Suzuki, T., Arai, S., Arai, T., and Shibasaki, M., J. Am. Chem. Soc. 114, 4418 (1992).

15.Arai, T., Yamada, Y. M. A., Yamamoto, N., Sasai, H., and Shibasaki, M., Chem. Eur. J. 2, 1368 (1996).

16.Trost, B. M. and Yeh, V. S. C., Org. Lett. 16, 2621 (2002).

17.Trost, B. M. and Yeh, V. S. C., Angew. Chem., Int. Ed. Engl. 41, 861 (2002).

18. Christensen, C., Juhl, K., Hazell, R. G., and Jřrgensen, K. A., J. Org. Chem. 67, 4875 (2002).

19. Evans, D. A., Seidel, D., Rueping, M., Lam, H. W., Shaw, J. T., and Downey, C. W., J. Am. Chem. Soc. 125, 12692 (2003).

20. Sasai, H., Watanabe, S., Suzuki, T., and Shibasaki, M., Org. Synth. Coll. 10, 571 (2004).

21. Palomo, C., Oiarbide, M., and Laso, A., Angew. Chem., Int. Ed. Engl. 44, 3881 (2005).

22. Luzzio, F. A., Tetrahedron 57, 915 (2001).

23. Sedlák, M., Drabina, P., Císařová, I., Růžička, A., Hanusek, J., and Macháček, V., Tetrahedron

Lett. 45, 7723 (2004). 